\title{
Gender-Specific Effect of Mthfr Genotype and Neonatal Vigabatrin Interaction on Synaptic Proteins in Mouse Cortex
}

\author{
Elinor Blumkin 1,2, Tamar Levav-Rabkin ${ }^{1,2}$, Osnat Melamed ${ }^{1,2}$, Dalia Galron' and Hava M Golan*,1,2 \\ 'Department of Developmental Molecular Genetics, Faculty of Health Sciences, Ben-Gurion University of the Negev, Beer-Sheva, Israel; \\ ${ }^{2}$ Zlotowski Center for Neuroscience, Ben-Gurion University of the Negev, Beer-Sheva, Israel
}

\begin{abstract}
The enzyme methylenetetrahydrofolate reductase (MTHFR) is a part of the homocysteine and folate metabolic pathways, affecting the methylations of DNA, RNA, and proteins. Mthfr deficiency was reported as a risk factor for neurodevelopmental disorders such as autism spectrum disorder and schizophrenia. Neonatal disruption of the GABAergic system is also associated with behavioral outcomes. The interaction between the epigenetic influence of Mthfr deficiency and neonatal exposure to the GABA potentiating drug vigabatrin (GVG) in mice has been shown to have gender-dependent effects on mice anxiety and to have memory impairment effects in a genderindependent manner. Here we show that Mthfr deficiency interacts with neonatal GABA potentiation to alter social behavior in female, but not male, mice. This impairment was associated with a gender-dependent enhancement of proteins implicated in excitatory synapse plasticity in the female cortex. Reelin and fragile $X$ mental retardation I protein (FMRP) levels and membrane GluRI/GluR2 ratios were elevated in wild-type mice treated neonatally with GVG and in Mthfr + I- mice treated with saline, but not in Mthfr + I- mice treated with GVG, compared with control groups (wild type treated with saline). A minor influence on the levels of these proteins was observed in male mice cortices, possibly due to high basal protein levels. Interaction between gender, genotype, and treatment was also observed in the GABA pathway. In female mice, GABA A 2 /gephyrin ratios were suppressed in all test groups; in male mice, a genotype-specific enhancement of GABA A 2 2/gephyrin was observed. The lack of an effect on either reln or Fmrl transcription suggests posttranscriptional regulation of these genes. Taken together, these findings suggest that Mthfr deficiency may interact with neonatal GABA potentiation in a gender-dependent manner to interrupt synaptic function. This may illustrate a possible mechanism for the epigenetic involvement of Mthfr deficiency in neurodevelopmental disorders.
\end{abstract}

Neuropsychopharmacology (201 I) 36, 17|4-1728; doi:10.1038/npp.20 I I.52; published online I3 April 20 I I

Keywords: sociability; cerebral cortex; FMRI; reelin; GluRI

\section{INTRODUCTION}

Methylenetetrahydrofolate reductase (MTHFR) is a regulatory enzyme involved in the homocysteine and folate metabolic pathways. MTHFR directs folic acid either to nucleotide synthesis or to the methylations of DNA, RNA, proteins, and lipids by converting homocysteine to methionine, and subsequently synthesizing the methyl donor $S$-adenosylmethionine (SAM).

The $677 \mathrm{C}>\mathrm{T}$ variant is a polymorphism in the Mthfr gene leading to reduced activity and impaired folate status of the enzyme, and it is a common genetic cause of mild

*Correspondence: Dr HM Golan, Department of Developmental Molecular Genetics, Faculty of Health Sciences, Ben-Gurion University of the Negev, Beer-Sheva 84 I05, Israel, Tel: +972 86479974 ,

Fax: +97286276215, E-mail: havag@bgu.ac.il

Received I October 2010; revised 3 February 201।; accepted II March 201। hyperhomocysteinemia under impaired folate status (Frosst et al, 1995; Jacques et al, 1996; Kluijtmans et al, 2003). The Mthfr polymorphism has been associated with neurodevelopmental disorders such as schizophrenia (Gilbody et al, 2007; Regland et al, 1997; Feng et al, 2009; Vares et al, 2010) and autism (Boris et al, 2004; Goin-Kochel et al, 2009).

In mice, MTHFR activity is absent in Mthfr-deficient homozygous mice and reduced to $60-70 \%$ of that of wildtype (WT) littermates in heterozygous mice. This level of MTHFR enzymatic activity is comparable to the levels of activity observed in human beings with the $677 \mathrm{C}>\mathrm{T}$ polymorphism. Both heterozygous and homozygous mice exhibit hyperhomocysteinemia and reduced global DNA methylation compared with WT littermates (Chen et al, 2001).

Several antiepileptic drugs (AEDs) have been shown to interfere with homocysteine-folate metabolism, increasing homocysteine levels and decreasing those of folate, either dependent or independent of the presence of the $677 \mathrm{C}>\mathrm{T}$ Mthfr mutation (Ono et al, 2002; Sener et al, 2006; Vilaseca 
et al, 2000; Vurucu et al, 2008; Yoo and Hong, 1999). The effects of the newer anticonvulsants on homocysteine-folate metabolism, however, are not as extensively documented.

AEDs act via a variety of mechanisms, and the members of one AED category potentiate the efficacy of the GABAergic system. In the immature brain, GABA is a developmental signal involved in various aspects of cell cycle, migration, morphogenesis, and synaptogenesis (Wang and Kriegstein, 2009). Vigabatrin (GVG) is a new class of AED that blocks GABA degradation by inhibition of GABA transaminase (Mumford and Cannon, 1994). Neonatal exposure to GABA-potentiating drugs, at the age when GABA is converted from a depolarizing to a hyperpolarizing agent, was previously shown to induce long-lasting behavioral consequences, including learning and memory impairment in human and animal models (Dessens et al, 2000; Qume et al, 1995; Qiao et al, 2000; Levav et al, 2004, 2008; Volpe, 2001) and modified synaptogenesis in mice (Levav et al, 2008).

We have previously reported the behavioral consequences of $M t h f r$ deficiency and the combination between the $M t h f r+/-$ genotype and neonatal exposure to the GABApotentiating drug GVG in mice. An analysis of mice exploration in an open-field test revealed gender-dependent effects of $M t h f r+/-$ genotype and treatment. In contrast, recognition memory was impaired similarly by $M t h f r+I-$ genotype and GVG treatment in both genders (LevavRabkin et al, 2011).

Autism and schizophrenia are multifactorial disorders in which multi-gene inheritance and epigenetic factors are involved. Among the candidate genes, reln has an important role in brain development and synaptic plasticity. The reelin signaling pathway via apolipoprotein E receptor 2 and very low-density lipoprotein receptor, mediated by Disabled1 (Dab1) phosphorylation, promotes spine and synapse development and maturation (Niu et al, 2004; Qiu and Weeber, 2007), as well as synaptic plasticity (Beffert et al, 2005; Pujadas et al, 2010) via regulation of PSD95 and NMDA and AMPA receptors (AMPARs) (Niu et al, 2008; Qiu et al, 2006). Another gene associated with autism, fragile $\mathrm{X}$ mental retardation $1(F m r 1)$, is involved in the regulation of dendritic spine shape and function (Bagni and Greenough, 2005; Weiler and Greenough, 1999). Fmr1 protein (FMRP) particularly regulates the local synthesis of the AMPAR subunits GluR1 and their trafficking to the synapse (Suvrathan et al, 2010; Nakamoto et al, 2007; Hu et al, 2008).

As both reln and Fmrl gene transcriptions are regulated by CpG methylation of a tri-nucleotide repeat in the promoter region (Dong et al, 2005; Hansen et al, 1992) and both play central roles in spine formation and glutamatergic synapse function, we hypothesized that the levels of these proteins will be modified in Mthfr-deficient mice. Moreover, altered regulation of these proteins may affect the levels and compartmentalization of glutamate receptors.

To further characterize the behavioral outcome in the Mthfr heterozygote mice, we examined their sociability (Moy et al, 2004). Subsequently, the levels of reelin, FMRP, and associated proteins in cytoplasmic and plasma membrane-enriched fractions were measured. Finally, we examined the possibility that DNA methylation status is involved in the regulation of these genes.

\section{METHODS}

\section{Study Design}

Offspring of mice on a Balb/cAnNCrlBR background (kindly provided by Prof. Rima Rozen, McGill University, Montreal, QC, Canada) were marked by toe clipping on postnatal day (P) 4 and randomly assigned to one of four groups: WT and $M t h f r+/-$ mice injected with either saline (Sa-WT, Sa-Mthfr+l-) or GVG (GVG-WT, GVG$M t h f r+/-)$. Treatment was applied daily during the light cycles of P4-10 by subcutaneous injections of saline or GVG (50 mg/kg; Sigma-Aldrich, St Louis, MO) in a volume of $50 \mu \mathrm{l}$. All mice tested were the offspring of an $M t h f r+/-$ female and a WT male. A maximum of two offspring from each litter were included in a group to reduce the effects of litter maternal care and to increase variability. In all experiments, female mice were tested regardless of their estrus cycle status. The mouse colony was maintained in a $12: 12 \mathrm{~h}$ light/dark schedule; food and water were provided ad libitum. All procedures were performed according to guidelines of the Israeli Council on Animal Care and approved by the Animal Care and Use Committee of Ben-Gurion University of the Negev.

\section{Mthfr Genotyping}

Offsprings were genotyped as described previously (Chen et al, 2001), using polymerase chain reaction (PCR) amplification of DNA isolated from toe clips. The three primers used in the PCR analysis were as follows: sense primer 1 (5'-GAAGCAGAGGGAAGGAGGCTTCAG- $\left.3^{\prime}\right)$ in exon 3 , sense primer 2 ( $5^{\prime}$-AGCCTGAAGAACGAGATCAGCAG $\left.\mathrm{C}-3^{\prime}\right)$ in the $n e o^{r}$ gene, and antisense primer $3\left(5^{\prime}\right.$-GACTA GCTGGCTATCCTCTCATCC- $3^{\prime}$ ) in intron 3.

\section{Subcellular Fractionation}

Subcellular fractionation was performed as described by Huttner et al (1983) and Berton et al (2000). Mouse cerebral cortex was homogenized in the presence of protease inhibitors (Sigma-Aldrich) with a hand grinder (15 strokes) in $0.3 \mathrm{ml}$ homogenization buffer $(0.32 \mathrm{M}$ sucrose, $5 \mathrm{mM}$ Tris-base, $\mathrm{pH}$ 7.4). Homogenates were centrifuged for $10 \mathrm{~min}$ at $800 \mathrm{~g}$. The resulting supernatant was collected and centrifuged for $15 \mathrm{~min}$ at $9200 \mathrm{~g}$, and the supernatant obtained (S2) was used as the crude cytoplasmic fraction. The pellet was suspended in $25 \mu$ l homogenization buffer and centrifuged for $15 \mathrm{~min}$ at $10200 \mathrm{~g}$ to yield a supernatant and the crude synaptosomal fraction $\left(\mathrm{P}^{\prime}\right)$. A dilution of $\mathrm{P} 2^{\prime}$ (1:9 ratio) in ice-cold water was subjected to several strokes, and $1 \mathrm{M}$ Tris-base ( $\mathrm{pH} 7.4$ ) was added to the resulting $\mathrm{P} 2$ '-lysate $(\mathrm{L})$, which was kept on ice for $30 \mathrm{~min}$. The lysate was centrifuged for $30 \mathrm{~min}$ at $25000 \mathrm{~g}$ to yield a plasma membrane-enriched fraction (LP1). The samples were kept at $4{ }^{\circ} \mathrm{C}$ during the entire fractionation process.

\section{Immunoblot Analysis}

Proteins were separated by 6 and $7.5 \%$ sodium dodecyl sulfate-polyacrylamide gel electrophoresis (SDS-PAGE) under reducing conditions. Membranes were probed with the following primary antibodies: rabbit-anti-GAD65/67 
(1:5000), rabbit anti-GluR1 $(1: 1000)$, mouse anti-FMRP $(1: 2500$; Chemicon International, Temecula, CA), mouse anti-GABA A, $\alpha 2$ subunit $(1: 1000)$, mouse anti-reelin (1:1000), rabbit anti-Dab1 (1:2000; Abcam, Austin, TX), mouse anti-gephyrin (1:10 000; Synaptic System, Goettingen, Germany), and mouse anti- $\beta$-actin (1:10000; SigmaAldrich). Goat anti-mouse IgG (1:10 000; Chemicon International) and goat anti-rabbit IgG horse-radish peroxidase (HRP)-conjugated secondary antibody $(1: 5000-1: 10000$; Upstate, Lake Placid, NY) were used for detection. Visualization was obtained with an enhanced chemiluminescence system by XRS Chemiluminescence imager (Bio-Rad). Quantification was performed with the TINA software (Raytest, Straubenhardt, Germany). The results of each trial were normalized to the trial mean. In the reelin analysis, where three fragments were detected, the reelin/ actin ratio was normalized separately for each fragment. Two to four independent repeats of each sample was averaged (each repeat included a duplicate of each sample). All immunoblot results represent the crude cytoplasmic fraction, unless otherwise stated.

\section{Real-Time PCR}

RNA was isolated using RNA isolation kit-EZ-RNA (Biological Industries, Beit Haemek, Israel). RNA samples were quantified using a Nanodrop Spectrophotometer (Nanodrop Technologies). Synthesis of cDNA was performed using the High-Capacity cDNA Reverse Transcription Kits (Applied Biosystems) in a PCR-T personal thermocycler (Biometra, Goettingen, Germany). Triplicate Q-PCR amplifications were performed using $2 \mu \mathrm{l}$ of cDNA in a total volume of $50 \mu \mathrm{l}$ using Real-Time PCR-KAPA SYBR FAST qPCR Kit (Kapa Biosystems, Cambridge , MA), and specific primers were targeted using conditions defined in preliminary experiments. All assays were performed as realtime Q-PCR using actin as a normalizer. For primer details see Supplementary Material 1. Assays were run on an iCycler, My IQ (Bio-Rad).

\section{Methylation Analysis of Genomic Fmr1 Gene}

Genomic DNA was extracted from mouse brain using the Puregene kit provided by Gentra. DNA was digested by a combination of the methylation-sensitive enzyme EagI and the methylation-insensitive enzyme EcoRI. Digested fragments were separated by electrophoresis on a $2.4 \%$ agarose gel, transferred to a positively charged membrane, and probed with a $569 \mathrm{bp}$ DIG-labeled probe that hybridized to a sequence adjacent to the CGG repeat region in the $5^{\prime}$-UTR of Fmrl. Primers used to prepare the probe were as follows: forward, 5'-GTTCTGGCACACCCTATTGGC- ${ }^{\prime}$; reverse, 5' CCTGTAAACAGTCAAACGATG-3'. Anti-DIG HRP antibody was used to visualize the probe. A fragment of $3163 \mathrm{bp}$ indicates that the 3361 locus in the tested region is methylated (according to NCBI gi: 149271867). A fragment of $1159 \mathrm{bp}$ indicates that the 3361 locus is unmethylated.

\section{Protein Methylation Assay}

Supernatants of the tissue lysate $60 \mu \mathrm{g}$ of protein were incubated for $60 \mathrm{~min}$ at $37^{\circ} \mathrm{C}$ in a total volume of $30 \mu \mathrm{l}$ with
$1 \mu \mathrm{l}$ of $S$-adenosyl-L-[methyl- $\left.{ }^{14} \mathrm{C}\right]$ methionine $\left(\left[{ }^{14} \mathrm{C}\right]\right.$ AdoMet (Perkin-Elmer), $51.4 \mathrm{mCi} / \mathrm{mmol}$, in sulfuric acid:ethanol (9:1), $\mathrm{pH} 2.5-3.5)$ in $150 \mathrm{mM}$ HEPES buffer adjusted to $\mathrm{pH}$ 7.5 with Tris-base.

SDS gel sample buffer was added to the samples, which were then heated at $100^{\circ} \mathrm{C}$ for $3 \mathrm{~min}$. Proteins were separated by SDS-PAGE on 6 or 7\%, $0.75-\mathrm{mm}$-thick gel and transferred onto the BioTrace nitrocellulose membrane, which was exposed to Kodak BioMax MS film at $-80^{\circ} \mathrm{C}$ to obtain an autoradiograph.

\section{Adult Mouse Behavior}

Behavior of mice aged 16 weeks was videotaped and analyzed off-line with the Etho-vision Pro software (Noldus, the Netherlands). A week before the test, mice were separated to individual cages and handling was performed daily by the same experimenter who later performed the test. Mice were tested between 16:00 and 20:00 hours. The chambers were cleaned between trials with $70 \%$ ethanol.

\section{Olfactory Test}

Mice were removed from their cage and a cheese cube $\left(1 \mathrm{~cm}^{2}\right)$ was hidden in the cage bedding. Mice were put back in the cage, and the latency to locate the cheese was measured (Crawley, 1999).

\section{Preference for Social Novelty Test}

Initiation of social interaction was examined in a threechambered apparatus in which each chamber measured $40 \times 20 \times 22 \mathrm{~cm}^{3}$ (Figure 1a). Divider panels separated the center chamber from two identical side chambers. On the first day of the test, one of the chambers contained a cage with an unfamiliar adult mouse (Stranger1), whereas the other identical chamber contained an empty wire cage (Empty). Stranger1 had the same genetic background and gender as the subject mouse and had been habituated to the cage before the test.

The tested animal was placed in the middle compartment with the dividers closed for a 10-min adaptation period. The dividers were then raised, allowing the test subject to freely explore all three chambers over a 10-min test session. The wire cage was designed to ensure that initiation of social contact be made only by the test subject.

On the following day, preference for social novelty (Figure 1b) was evaluated. The original stranger mouse (Stranger1, now familiar mouse) remained in its cage on one side of the apparatus. An unfamiliar mouse (Stranger2) was placed in the wire cage in the opposite, previously empty chamber (Figure 1a). Measurements identical to those in the sociability test were scored in chambers Stranger1 (now familiar mouse), Center, and Stranger2 (unfamiliar mouse) (Crawley, 2007; Nadler et al, 2004).

\section{Statistical Analysis}

Statistical analyses were performed using the SPSS 14.0 software. A one-way analysis of variance, with a post hoc Dunnett's T3 test, was used to compare experimental and control groups. Univariate general linear model analysis 
a

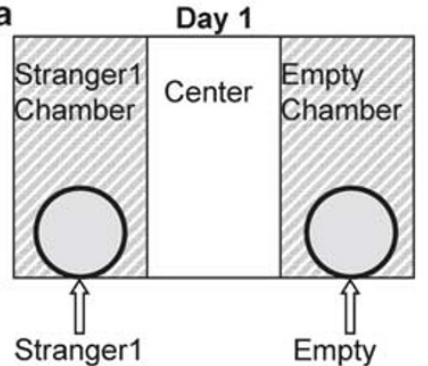
$c$

OO

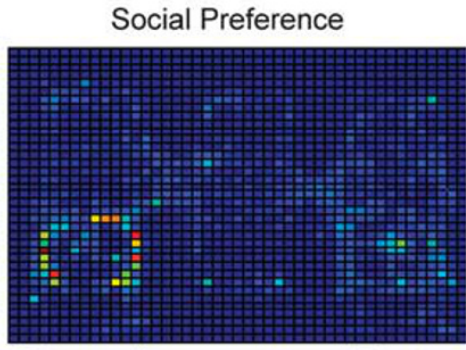

Stranger1

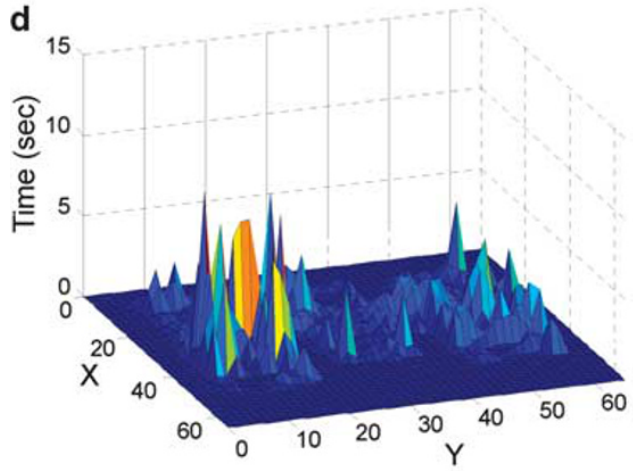

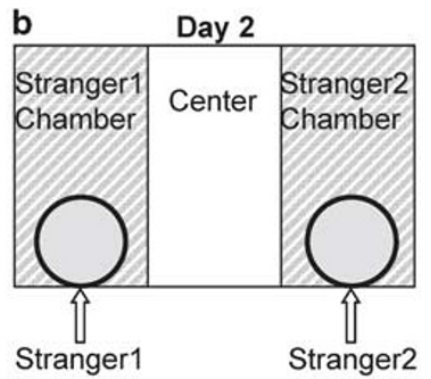

e
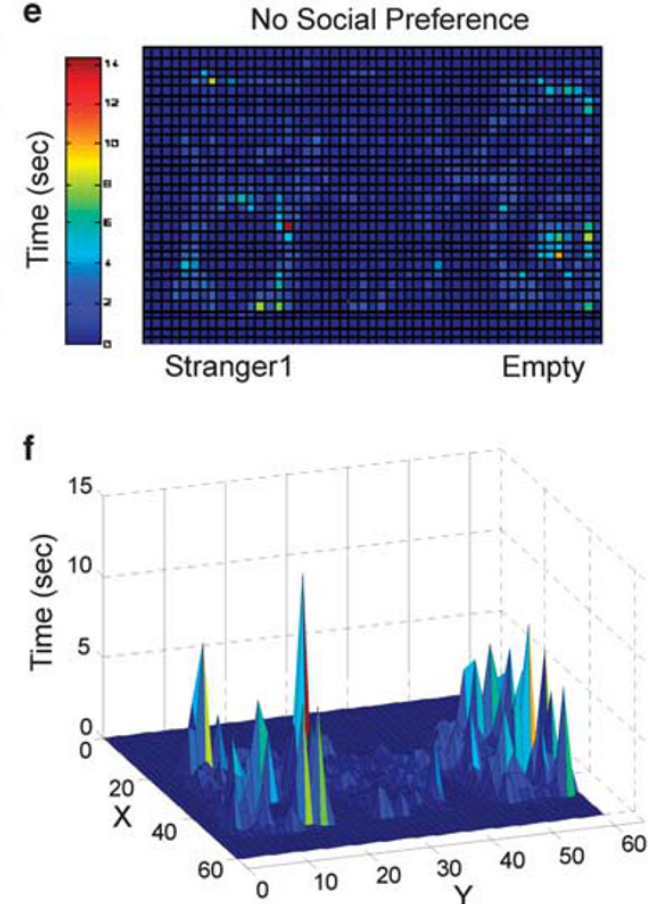

Figure I Social behavior analysis. In the social interaction test, mice were introduced on the first day to a three-chambered environment containing a stranger mouse, a central chamber, and a chamber with an empty cage (a). On day 2, mice were tested for preference for social novelty (b), in which mice were introduced to the same three-chambered environment containing the original stranger mouse (Strangerl), a central chamber, and a chamber with an unfamiliar mouse (Stranger2). The duration of time the mice spent at each location of the apparatus is illustrated by a heatmap (maximum value-red; minimal value-blue). An example of social preference, indicated by an increased duration of time spent in Strangerl chamber compared to empty chamber, is illustrated in (c, upper view) and (d, side view). An example of lack of social preference, indicated by a similar time spent in Strangerl chamber vs empty chamber, is depicted in (e, upper view) and (f, side view).

was used to test the effects of, and interactions between, two independent variables (genotype and treatment) or three independent variables (genotype, treatment, and gender). A two-tailed Student's $t$-test was used for statistical evaluation of the continuous variables when a comparison was performed between two groups and for a single time point. A $\chi^{2}$-test was used to statistically evaluate distributions for two-group comparisons. Differences with a $p$-value $<0.05$ were regarded as significant. Results are presented as the mean \pm SEM.

\section{RESULTS}

\section{Preference for Social Novelty}

As both the Mthfr-deficient background and the AED treatment have been shown to be associated with autisticlike behavior (Boris et al, 2004; Rasalam et al, 2005), we measured the effects of the genotype and neonatal GVG treatment on sociability. Before the social interaction tests, a gross sensory measurement for olfaction was performed to ensure proper olfactory communication. Latency to locate a hidden cheese cube was similar among all male groups and among all female groups (Supplementary Material 2).

On the first day of the social preference test, mice were introduced into a three-chambered environment containing a Stranger mouse (S1), a central chamber (C), and a chamber with an empty cage (E). A diagram of the setting is presented in Figure 1a. An example of social preference on the first day of the test, indicated by an increased duration of time spent in the Stranger1 chamber compared with the empty chamber, is illustrated as $2 \mathrm{D}$ and $3 \mathrm{D}$ heat maps in Figures 1c and d, respectively. An example of lack of social preference, indicated by similar amounts of time spent by the mouse in the Stranger1 chamber $v s$ in the Stranger2 chamber, is depicted in Figures $1 \mathrm{e}$ and $\mathrm{f}$. 
a
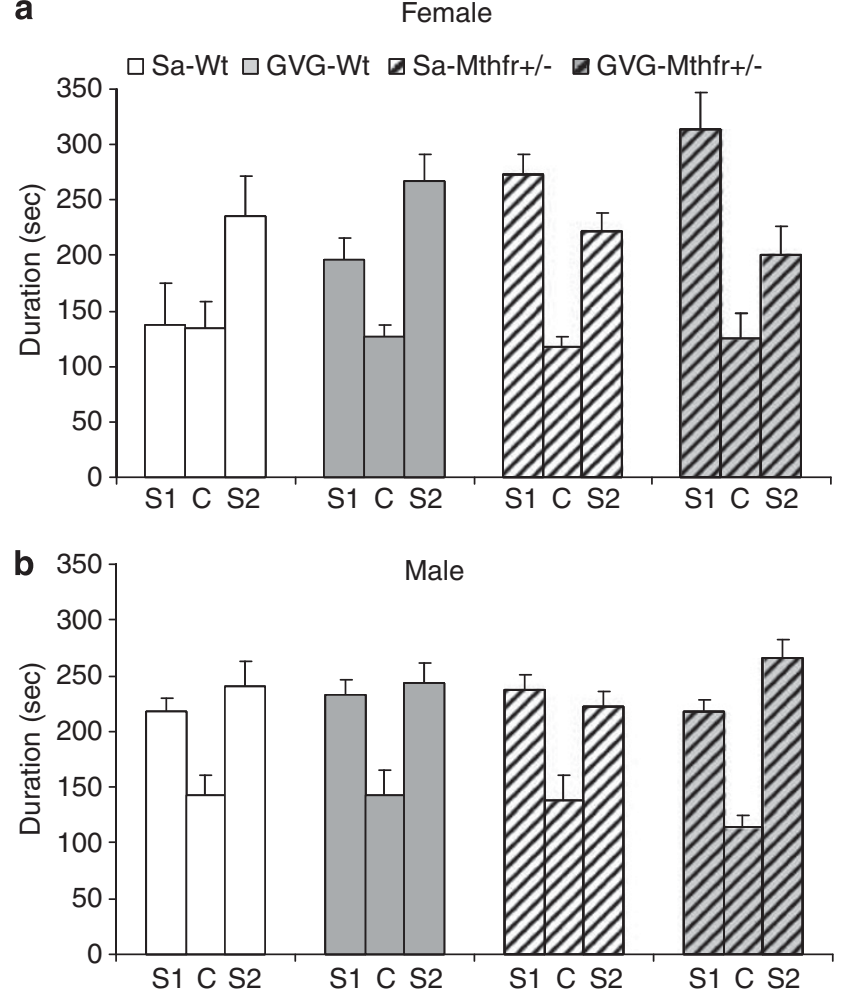

Figure 2 Gene-drug effects on preference for social novelty. The distribution patterns of duration in the Strangerl (SI), center (C), and Stranger2 (S2) chambers of adult female (a) and male (b) mice. $n=5-1$ I (male), $n=6-1 \mid$ (female). $\chi^{2}$-test was used for all analyses. Results are presented as mean \pm SEM. Female: $\chi^{2}$-tests for each group compared with saline-wild type (Sa-WT), $p<0.000$ I. Male: $\chi^{2}$-test for Sa-WT compared with vigabatrin (GVG)-Mthfr + / - mice, $p<0.01$.

Balb/c mice and related strains, such as Balb/cByJ and $\mathrm{Balb} / \mathrm{cAnNCrlBR}$, the last of which we tested in this study were reported to present low sociability (Moy et al, 2007, 2008; Panksepp et al, 2008; Chen et al, 2009; Jacome et al, 2011). In agreement with Moy et al (2007), on day 1 the control (Sa-WT) group spent more time in the central compartment, avoiding both the Strangerl and the empty cage compartments, indicating high levels of anxiety. Further analysis of sniffing time or the percent of social mice (those showing greater interest in the mouse compared with the empty cage) $v s$ asocial mice (greater interest in the empty cage compared with the mouse) (Moy et al, 2008) showed that the behavior of all experimental groups was asocial for these two variables (see Supplementary Material 2). Genotype or treatment did not influence mice sociability on the first day.

On the basis of the analysis of different mouse strains showing asocial behavior on the first but not the second day of the test, Moy et al (2007), suggested that the behavior of the mice in these two tests is mediated by different background genes.

On the second day, mice were tested for preference for social novelty (a setting of the test apparatus is shown in Figure $1 b)$.

The female mice of the Sa-WT group showed a preference for the unfamiliar mouse (Stranger2) compartment. The female mice of all test groups displayed a different distribution pattern of duration in the chambers $\left(p<0.0001, \chi^{2}\right.$-tests for each group compared to Sa-WT; Figure 2a).

In male mice, the distribution pattern of duration in the familiar mouse (Stranger1), center, and unfamiliar mouse (Stranger2) chambers was similar for Sa-WT, GVG-WT, and Sa-Mthfr $+1-$ groups $\left(p>0.05, \chi^{2}\right.$-tests for each group compared with Sa-WT; Figure 2b), whereas the distribution differed between Sa-WT and GVG-Mthfr $+1-$ mice $\left(p<0.01, \chi^{2}\right.$-test; Figure $\left.2 \mathrm{~b}\right)$, which spent more time in the unfamiliar Stranger2 chamber than in the familiar Stranger1 chamber $(p<0.01, t$-test; Figure $2 \mathrm{~b})$, a behavior which may indicate recognition of the familiar mouse and interest in the novel mouse.

Overall, social preference of female mice was affected by genotype, treatment, and the genotype-drug combination, and that of male mice was influenced by the combination of genotype and treatment.

\section{Influence of Mthfr Genotype and GVG Treatment on Reelin Signaling Proteins}

Females. Altered social behavior characterizes neurodevelopmental disorders such as autism and schizophrenia. An important protein associated with these disorders is reelin (Skaar et al, 2005; Serajee et al, 2006). The reelin pathway modulates synaptic activity and synaptic plasticity (Beffert et al, 2005; Pujadas et al, 2010). Upon secretion, reelin is cleaved into several fragments. The antibody used in this study detects three reelin fragments, $180 \mathrm{kDa}$, $\sim 300 \mathrm{kDa}$, and the full-length protein, $\sim 400 \mathrm{kDa}$ (Figure 3 ). In female cerebral cortex, an interaction between the effect of neonatal GVG treatment and the $M t h f r+1-$ genotype was detected for the heavy reelin fragments, whereas the $180-\mathrm{kDa}$ protein was insensitive to treatment or genotype (reelin $300 \mathrm{kDa}$, genotype $\times$ treatment, $\mathrm{F}=72.8, p<0.0001$; $400 \mathrm{kDa}, \mathrm{F}=42.4, p<0.0001)$. An enhancement of the 300 $\mathrm{kDa}$ protein by GVG and by genotype to 195 and $239 \%$ of control was observed in GVG-WT and Sa-Mthfr + Igroups, respectively. Levels of the $400-\mathrm{kDa}$ protein increased to 154 and $193 \%$ of control, respectively. In both the $300-\mathrm{kDa}$ and the full-length proteins, the combination of the $M t h f r+/-$ genotype and neonatal GVG treatment abolished the effect of genotype and treatment, and protein levels were 86 and $99 \%$ of control, respectively (Figure $3 a$ ). On the other hand, levels of Dab1, a reelin signaling protein, were not affected by either GVG or genotype alone, but the effect of GVG and genotype together tended to decrease Dab1 levels, which were $64 \%$ of control (Figure 3c).

Thus, in female cortex, reelin signaling was susceptible to the interaction between the $M t h f r+I-$ genotype and neonatal GVG treatment: each of these factors alone enhanced the pathway, but their combination may attenuate the response to reelin.

Males. In male cerebral cortex, reelin fragment levels were similar in all groups, whereas levels of the full-length protein were potentiated by genotype (156\% of control). This change in reelin levels was canceled when heterozygote mice were treated by GVG (Figure 3b), indicating an interaction between treatment and genotype $(\mathrm{F}=6.9, p<0.02)$.

Alternatively, the $M t h f r+/-$ genotype decreased Dab1 levels, independent of GVG treatment (genotype effect, 
a

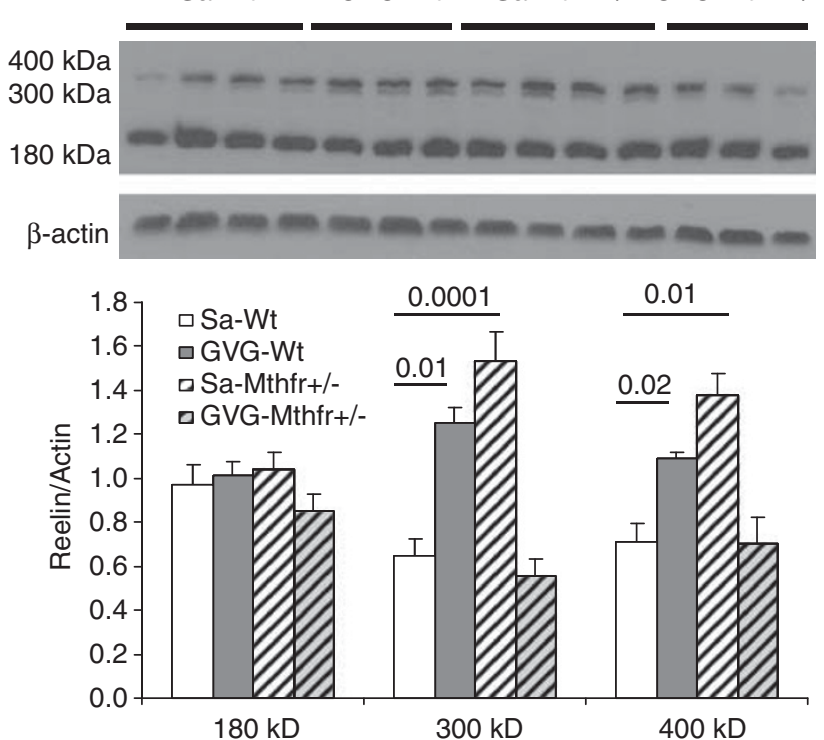

b

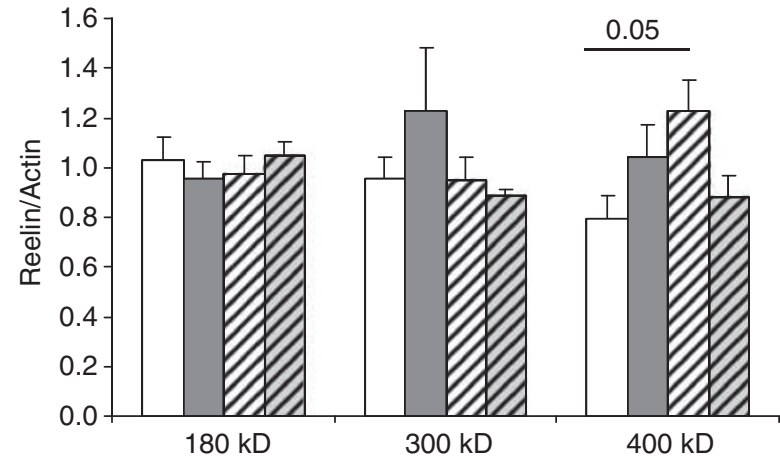

C
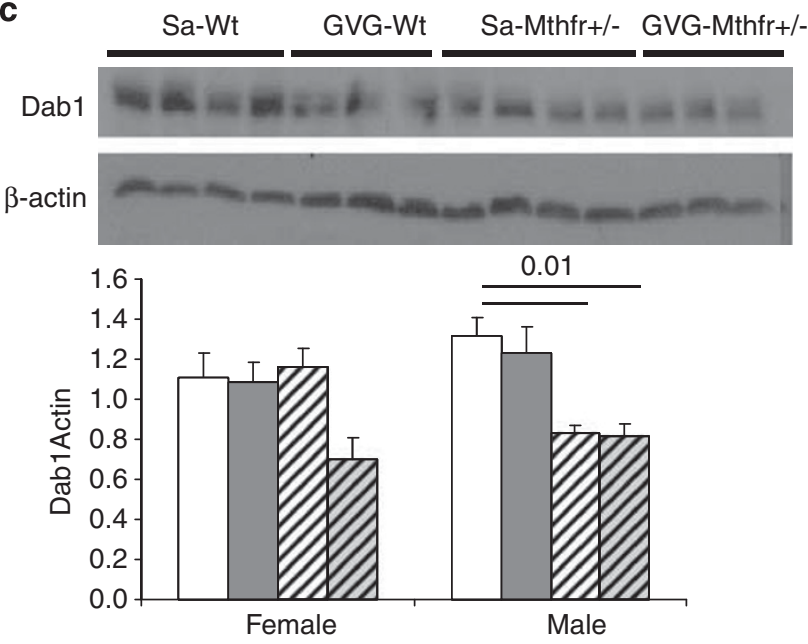

Figure 3 Effects of gender, genotype, and drug on reelin and Dab I levels in the cerebral cortex. An example of a reelin immunoblot of the female cortex is shown; the full-length protein, $\sim 400 \mathrm{kDa}$, and two products of proteolysis, $\sim 300$ and $180 \mathrm{kDa}$, were detected by the G-I0 anti-reelin antibody. Protein levels were normalized to actin. Reelin levels in female (a) and male (b) cerebral cortex cytoplasmic fractions. Female: reelin $300 \mathrm{kDa}$, effect of genotype $\times$ treatment, $F=72.8, p<0.000 \mathrm{I} ; 400 \mathrm{kDa}, F=42.4$, $p<0.000$ I, male: genotype $\times$ treatment, $400 \mathrm{kDa}, F=6.9, p<0.02$. An example of DabI in the male cortex and levels of Dab I normalized to actin in female and male mice (c). Male: genotype effect, $F=26.7, p<0.0001$. $n=7-8$ in each group. Results are presented as mean \pm SEM.
$\mathrm{F}=26.7, p<0.0001$ ), to 61 and $60 \%$ of control in the Sa-Mthfr+/- and GVG-Mthfr $+/-$ groups, respectively (Figure 3c).

Thus, reelin signaling in the cerebral cortex was differentially affected in female and male mice. Although in female mice reelin was enhanced by the effects of either GVG treatment or genotype alone and it may be suppressed by their combination, among male mice only the $M t h f r+/-$ mice were affected.

\section{Effect of Mthfr Genotype and GVG Treatment on Synaptic Proteins}

Females. Proteins such as FMRP that regulate excitatory synapses have been associated with autism spectrum disorder (Chonchaiya et al, 2009). An example of an FMRP blot is shown in Figure 4. In female mice, cerebral cortex FMRP levels were enhanced by treatment $(\mathrm{F}=4.45, p<0.05)$ and indicated an interaction between treatment and genotype $(\mathrm{F}=7.7, p<0.02)$. An increase in FMRP levels was observed in GVG-WT and Sa-Mthfr $+/-$ mice $(199 \%$, $159 \%$ of Sa-WT group, respectively), whereas neonatal GVG given to the $M t h f r+I-$ group prevented this effect (Figure 4a). FMRP is known to regulate GluR1 levels in synapses through the regulation of local synthesis. GluR1 levels in the cytoplasmic fraction of female cortex were not sensitive to either treatment or genotype (Figure $4 \mathrm{~b}$ ).

As a large portion of receptor proteins are found in the plasma membrane (Figure 4c), we tested the ratio between two AMPAR subunits, GluR1 and GluR2, in the plasma membrane-enriched fraction. The GluR1/GluR2 ratio showed an interaction between genotype and treatment $(\mathrm{F}=13.15, p<0.001)$. The ratio was significantly higher in the GVG-WT and Sa-Mthfr+/- groups compared with control (139 and 162\%, respectively), whereas in the heterozygote GVG-treated mice, GluR1/GluR2 was similar to control (Figure 4c).

Males. When the levels of FMRP in male cortex were examined, neither treatment nor genotype had any significant effect. However, GVG significantly modified GluR1 levels in the cytoplasmic fraction in a genotype-dependent manner. Although in WT mice GluR1 levels were potentiated by GVG (149\% of control), interaction with the $M t h f r+1-$ genotype caused a significant decrease in GluR1 levels in male cortex (77\% of control; Figure $4 \mathrm{~b})$. Similar GluR1/GluR2 ratios in the cerebral cortex plasma membrane-enriched fraction were detected in all male groups (Figure 4c).

Overall, the levels and distribution of the tested proteins critical for excitatory synapse function were markedly modified in female mice. Altered levels were found following neonatal GVG treatment and in the Mthfr + Ifemale mice, but not in GVG-treated $M t h f r+1-$ female mice. Minor effects were observed in male mice of all groups.

Female vs male. The remarkable difference in the sensitivity of components involved in the excitatory synapse function to genotype and treatment, in female compared with male mice, may be due to differences in the basal levels of these proteins in the female and male cortices. To address 

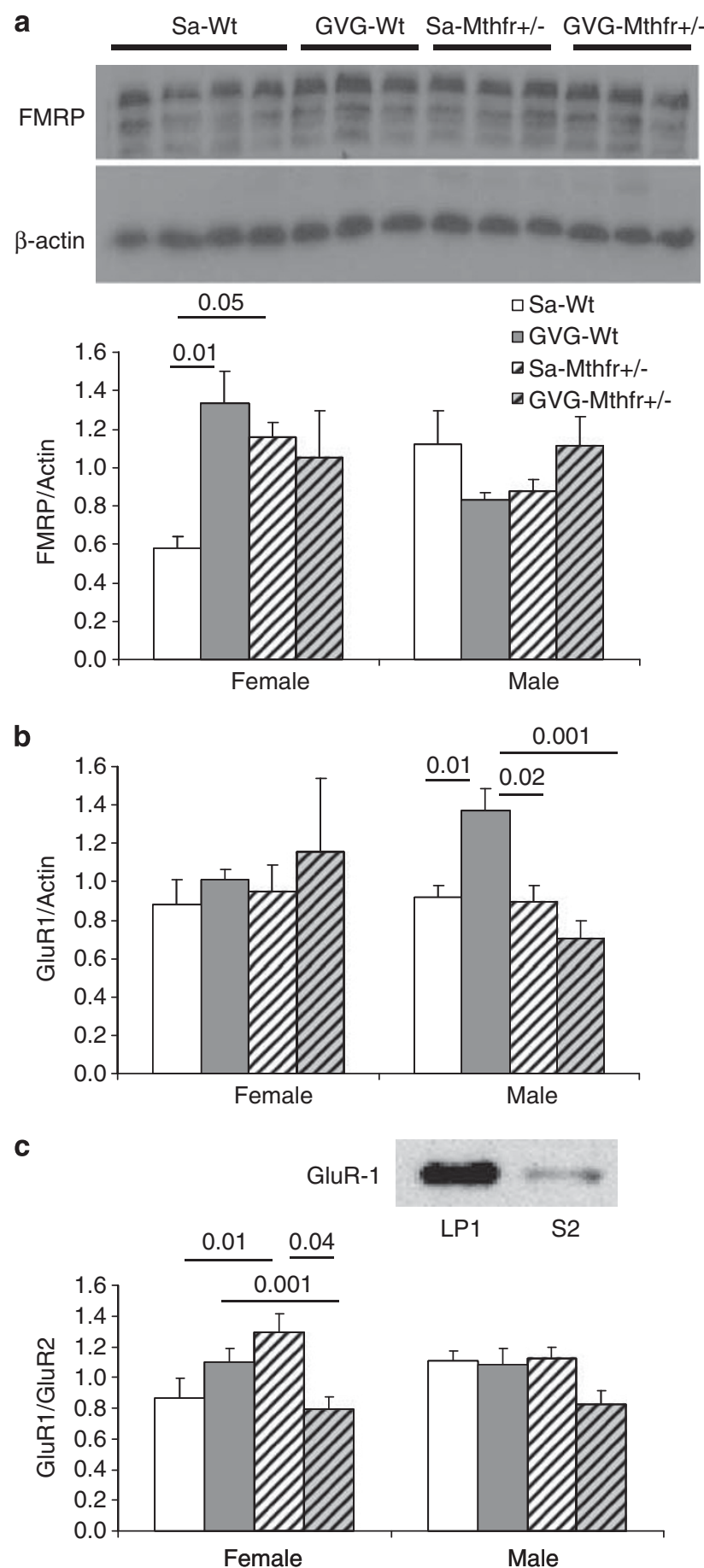

Figure 4 Effects of gender, genotype, and drug on fragile $X$ mental retardation I protein (FMRP) and glutamate receptor (GluR) levels in the cerebral cortex. An example of an FMRP immunoblot of the cytoplasmic fraction from the female cortex (a). Protein levels in cytoplasmic fractions were normalized to actin. FMRP (a) and GluRI (b) levels in female and male cerebral cortex cytoplasmic fraction. Female FMRP: effect of treatment, $F=4.45, p<0.05$; effect of treatment $\times$ genotype, $F=7.7$, $p<0.02$. An example of a GluRI immunoblot of the cytoplasmic fraction (S2) and the membrane-enriched fraction (LPI), indicating that the GluRI protein is enriched in the LPI fraction (c). The GluRI/GluR2 ratio in the LPI fraction of female and male mice (c). Female GluRI/GluR2 in LPI fraction; effect of genotype $\times$ treatment, $F=13.15, p<0.001 . n=7-8$ in each group. Results are presented as mean \pm SEM. this possibility, we compared the levels of FMRP, GluR1, and GluR2 in Sa-WT female and Sa-WT male cortices. FMRP levels were significantly elevated in the cytoplasm fraction of Sa-WT male cortex compared with Sa-WT female cortex ( $216 \%$ for female mice, $p<0.0001$; Figure $5 a)$. This was associated with a tendency for increased cytoplasm levels of GluR1 and GluR2 in Sa-WT male mice compared with Sa-WT female mice (data not shown). Furthermore, the GluR1/GluR2 ratio obtained in the membrane-enriched fraction of Sa-WT male mice was higher compared with SaWT female mice $(156.4 \%$ of female ratio, $p<0.03$; Figure 5B).

\section{Effect of $M t h f r+/-$ Genotype and GVG Treatment on Reln and Fmrl Expression}

Reln expression was tested by real-time PCR to explore the source of change in female cortex reln levels. The expression of reln in female cortex did not change in all tested groups (Figure 5c). Similar expression levels of Fmrl were found in the cortices of all female groups (Figure $5 \mathrm{~d}$ ).

Fmr1 expression is regulated by, among other mechanisms, DNA methylation. As hypomethylation has been reported in $M t h f r+/-$ mice (Chen et al, 2001), we explored the possible effects on Fmrl methylation patterns in female cortex. Methylation of the Fmrl 3361 locus adjacent to the $5^{\prime}$-UTR CGG repeat region was tested. This site was selected because in human beings, methylation of a homolog site predicts methylation of the CGG repeat region and the adjacent promoter of the Fmrl gene (Snow et al, 1993), which ultimately correlates with the silencing of the gene.

The pattern of methylation at this site in the Mthfr + Isamples was normal, as indicated by the presence of the two gene fragments of 3163 and $1159 \mathrm{bp}$ (Figure 5e). This pattern indicates that one allele of the gene underwent methylation controlled by the X-inactivation mechanism, whereas the other allele remained unmethylated, thus corresponding to the 3163- and 1159-bp fragments, respectively. This result is consistent with the lack of observed differences in Fmr1 expression in female cortex.

\section{GABA Pathway in the Cerebral Cortex}

Females. Social behavior is considerably altered by cortical inhibitory circuitry (Lewis et al, 1999). Moreover, neonatal modulation of GABA levels induced by GVG was previously shown to have long-term consequences for the GABA pathway (Levav-Rabkin et al, 2010). Therefore, we examined the effect of genotype and drug treatment on GABA pathway proteins. Increased levels of the GABA-synthesizing enzyme GAD65 were observed in the Sa-Mthfr+ Ifemale mice, but not in the GVG-Mthfr $+/-$ group (genotype effect, $\mathrm{F}=6.1, p<0.02$; Figure $6 \mathrm{a}$ ). We then examined the postsynaptic elements of the GABA A synapse, the GABA A 22 subunit, and the scaffolding protein gephyrin, the latter of which is critical for the assembly of GABA A receptors in the inhibitory synapse, in the female cerebral cortex.

GVG treatment induced a significant decrease in GABA $\mathrm{A} \alpha 2$ levels independent of genotype in female mice $(\mathrm{F}=9.01, p<0.01$; Figure $6 \mathrm{~b}) . \mathrm{GVG}$ treatment reduced 

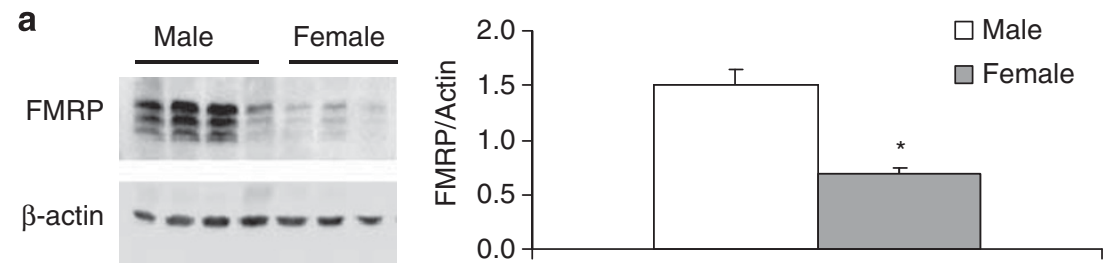

b
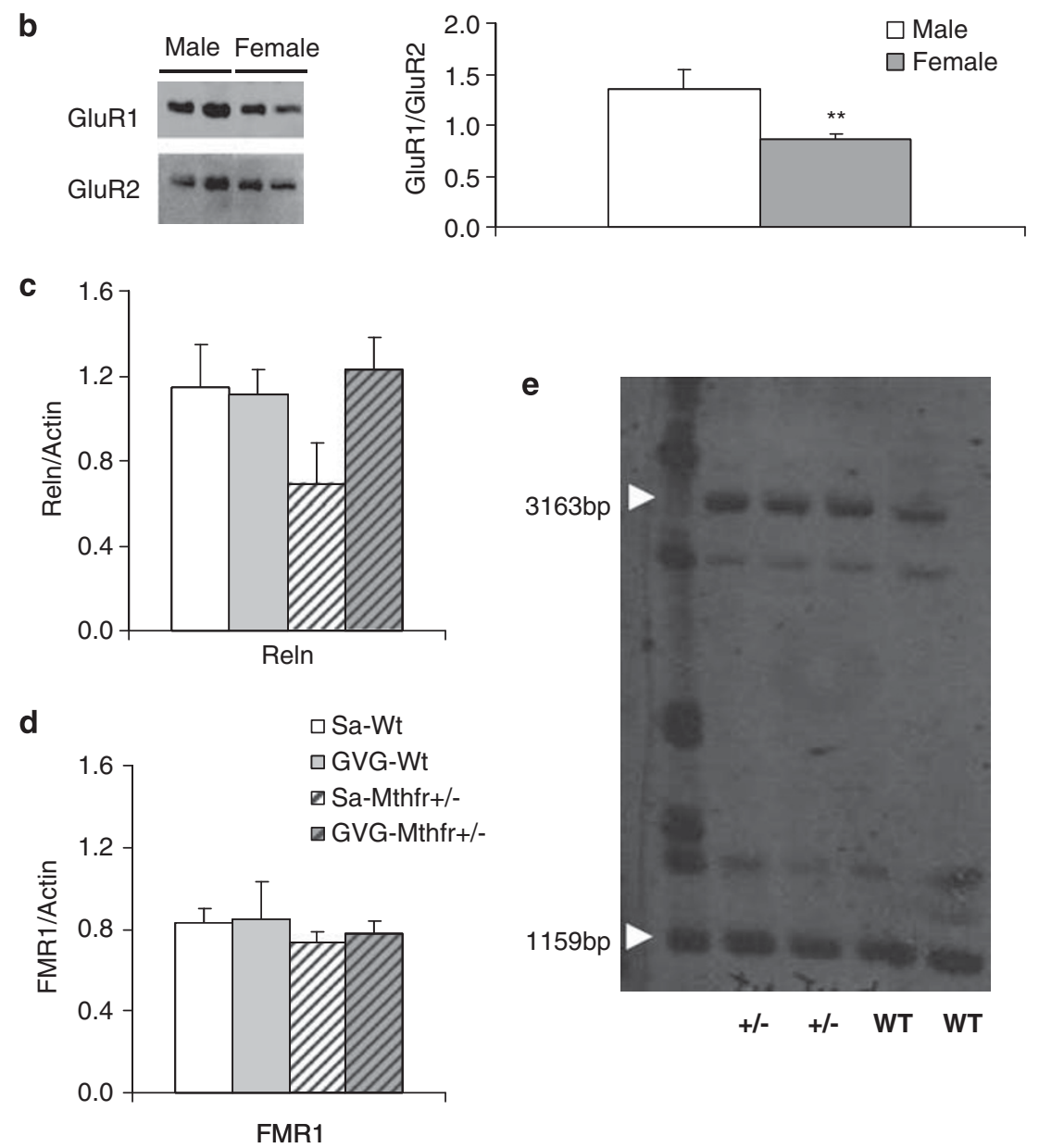

Figure 5 Effects of gender and genotype on protein, mRNA, and DNA methylation in the cerebral cortex. Fragile $X$ mental retardation I protein (FMRP) levels in the S2 fraction were compared in male and female mice cerebral cortices (a). The glutamate receptor (GluR) I/GluR2 ratio in the plasma membrane-enriched fraction (LPI) fraction in male and female mice was compared (b). $n=5$ in each group. Real-time PCR analysis of reln and Fmrl in female cortex (c and d, respectively). $n=8-9$ in each group. (e) An example of a Southern blot DNA was digested by a combination of the methylationsensitive enzyme Eagl and the methylation-insensitive enzyme EcoRI. DNA was probed with a 569-bp DIG-labeled probe that hybridized to a sequence adjacent to the CGG repeat region in the 5'-UTR of Fmrl. Results are presented as mean \pm SEM. $* p<0.000$ I; $* *$ p $<0.05$.

gephyrin levels in the cytoplasmic fraction of female cortex $(\mathrm{F}=16.1, \quad p<0.001)$, and in female cortices in the $M t h f r+I-$ genotype group, significantly decreased levels of gephyrin were observed $(\mathrm{F}=40.16, p<0.0001)$. Moreover, treatment and genotype interact, increasing $M t h f r+I-$ female susceptibility to GVG treatment (treatment $\times$ genotype: $\mathrm{F}=5.03, p<0.05$; Figure $6 \mathrm{c}$ ).

The ratio between GABA A $\alpha 2$ and gephyrin in the plasma membrane-enriched fraction extracted from female cortex was significantly suppressed by GVG $(\mathrm{F}=10.01, p<0.005)$ and in the $M t h f r+I-$ genotype mice $(\mathrm{F}=44.7, p<0.0001)$ and in GVG-Mthfr + I- genotype combination mice (67, 47 , and $52 \%$ of control, respectively) (Figure 5d). An interaction between treatment and genotype was observed $(\mathrm{F}=13.01, p<0.002)$.
Males. In male cortex, levels of the presynaptic-synthesizing enzyme GAD65 were reduced in the Sa-Mthfr + I- mice, whereas the combination of GVG and $M t h f r+I-$ prevented this effect (Figure 6a). Levels of the postsynaptic proteins GABA A $\propto 2$ and gephyrin were not sensitive to $M t h f r+I-$ genotype and treatment. On the other hand, the GABA A $\alpha 2$ / gephyrin ratio potentiated in the plasma membrane of Mthfr genotype mice to 134 and $189 \%$ of the control group in the Sa-Mthfr $+/-$ and GVG-Mthfr $+/$ - groups, respectively (genotype effect: $\mathrm{F}=14.2, \quad p<0.02$ and genotype $\times$ treatment interaction: $\mathrm{F}=8.2, p<0.01$; Figure $6 \mathrm{~d}$ ).

Overall, the GABA pathway was modified by the $M t h f r+I-$ genotype and by neonatal GVG treatment in a gender-dependent manner such that the components affected in female and male mice differed. 
Effect of $M t h f r+/-$ Genotype and GVG Treatment on Protein Methylation in the Female Brain

MTHFR deficiency interferes with the levels of SAM, a major methyl donor for protein, RNA, and DNA methylation,

a
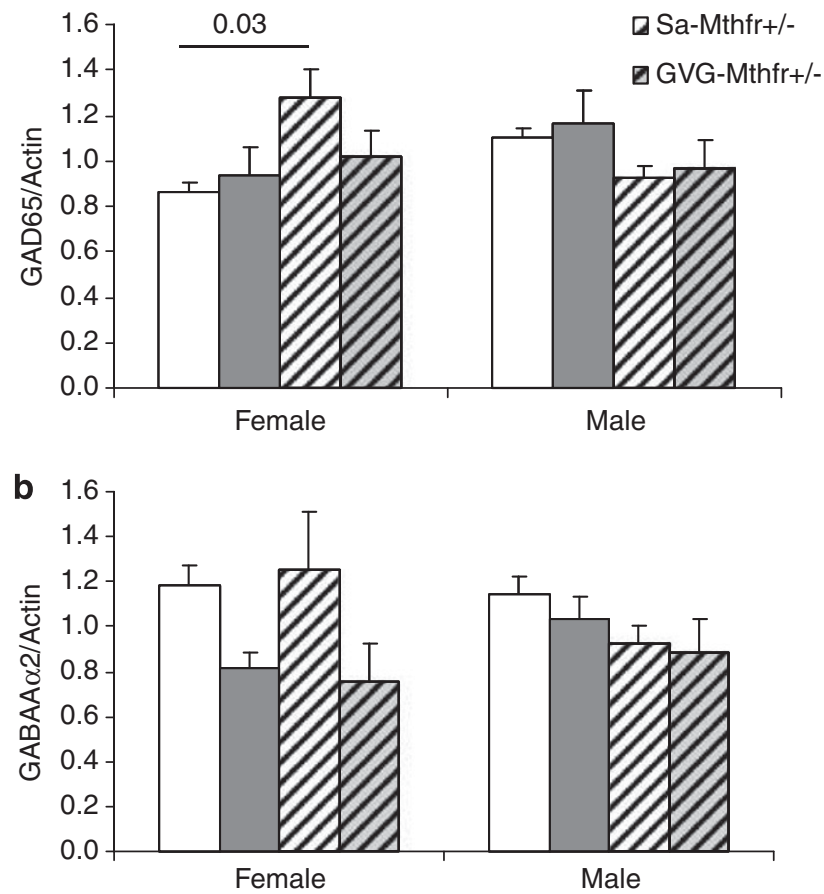

c

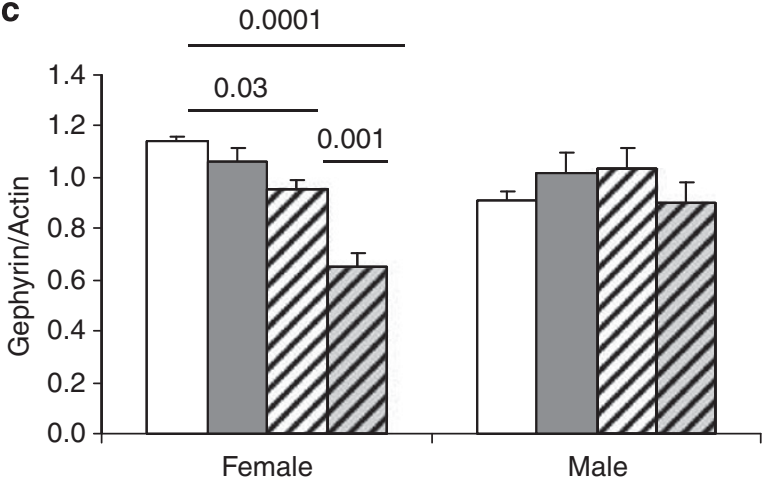

d

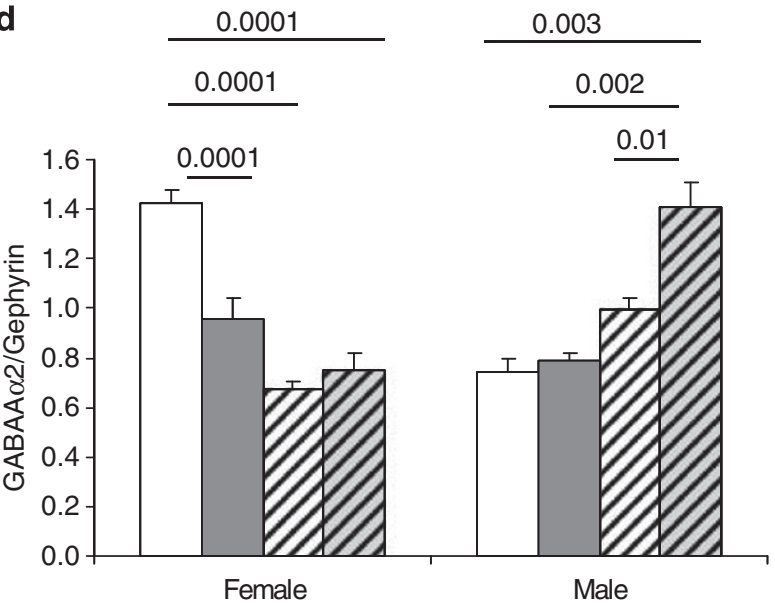

and protein function may be modulated by methylation. We performed a methylation assay on proteins extracted from tissue homogenates of female mice. An example of the results is shown in Figure 7a. An intense radiolabel was detected in P4 knockout brain homogenate (lanes 2 and 4 ), a lower intensity was obtained in P4 WT, whereas P120 WT exhibited a very light radiolabel, as expected from the age-dependent increase in protein methylation in P120 WT mice. Samples of all tested groups (P120) were compared, and no significant differences were detected between the various groups (Figure $7 b$ ). Line intensity analyses were performed for the cortex, hippocampus, and cerebellum homogenates (Figures $7 \mathrm{c}-\mathrm{e}$, respectively). The female cortex radiolabel in all treatment groups was similar to that of the Sa-WT group (Figure 7c).

\section{DISCUSSION}

This is the first reported study of molecular changes induced by the interaction between gender, Mthfr deficiency, and neonatal exposure to the AED GVG. Genotype and treatment has a significant effect on female social preference. This behavioral outcome was associated with the cortical potentiation of reelin levels and altered the proportions of important proteins in the excitatory and inhibitory synapses. Most protein modifications occurred in the female cortex, however, with only negligible levels observed in the male cortex. The significant changes observed in excitatory and inhibitory synapse protein levels may underlie the mechanisms of social preference impairment and anxiety previously observed in the tested mice.

The susceptibility of the developing brain to Mthfr deficiency has not been appreciated until recently, when an increasing number of reports began to suggest it as a risk factor for neurodevelopmental disorders such as schizophrenia and autism. Although an interaction between $M t h f r$ deficiency and AEDs has been suggested to enhance the effect of AEDs on offspring (Dean et al, 1999), a study in Mthfr heterozygote mice showed that an interaction between the AED valproic acid (VPA) and Mthfr deficiency diminished VPA-induced neural tube defects, owing to the upregulation of Mthfr expression by VPA (Roy et al, 2008).

The effects of the newer anticonvulsants on homocysteine-folate metabolism are not as extensively documented. GVG, which inhibits GABA transaminase, is known for the specificity of its effect on neuronal function (Mumford and

Figure 6 Effects of gender, genotype, and drug on $\gamma$-aminobutyric acid (GABA) pathway proteins in the cerebral cortex. The levels of GAD65 (a), GABA A $\alpha 2$ (b), and gephyrin (c) levels normalized to actin levels in the cytoplasmic fractions of female and male cerebral cortices. Female, GAD65: effect of genotype $F=6.1, p<0.02$. GABA A $\alpha 2$ : effect of vigabatrin (GVG), $F=9.01, p<0.01$. Gephyrin: effect of GVG, $F=16.1, p<0.001$, effect of genotype, $F=40.16, p<0.0001$, genotype $\times$ treatment, $F=5.03, p<0.05$ The GABA A $\alpha 2 /$ gephyrin ratio in the plasma membrane-enriched fraction of male and female cerebral cortices (d). Female GABA A $\alpha 2 /$ gephyrin: effect of GVG, $F=10.01, p<0.005$, effect of genotype, $F=44.7$, $p<0.0001$, effect of treatment $\times$ genotype, $F=13.01, p<0.002$. Male GABA A $\alpha 2 /$ gephyrin: genotype effect, $F=14.2, p<0.02$, effect of genotype $\times$ treatment, $F=8.2, p<0.01 . n=7-8$ in each group. Results are presented as mean \pm SEM. 

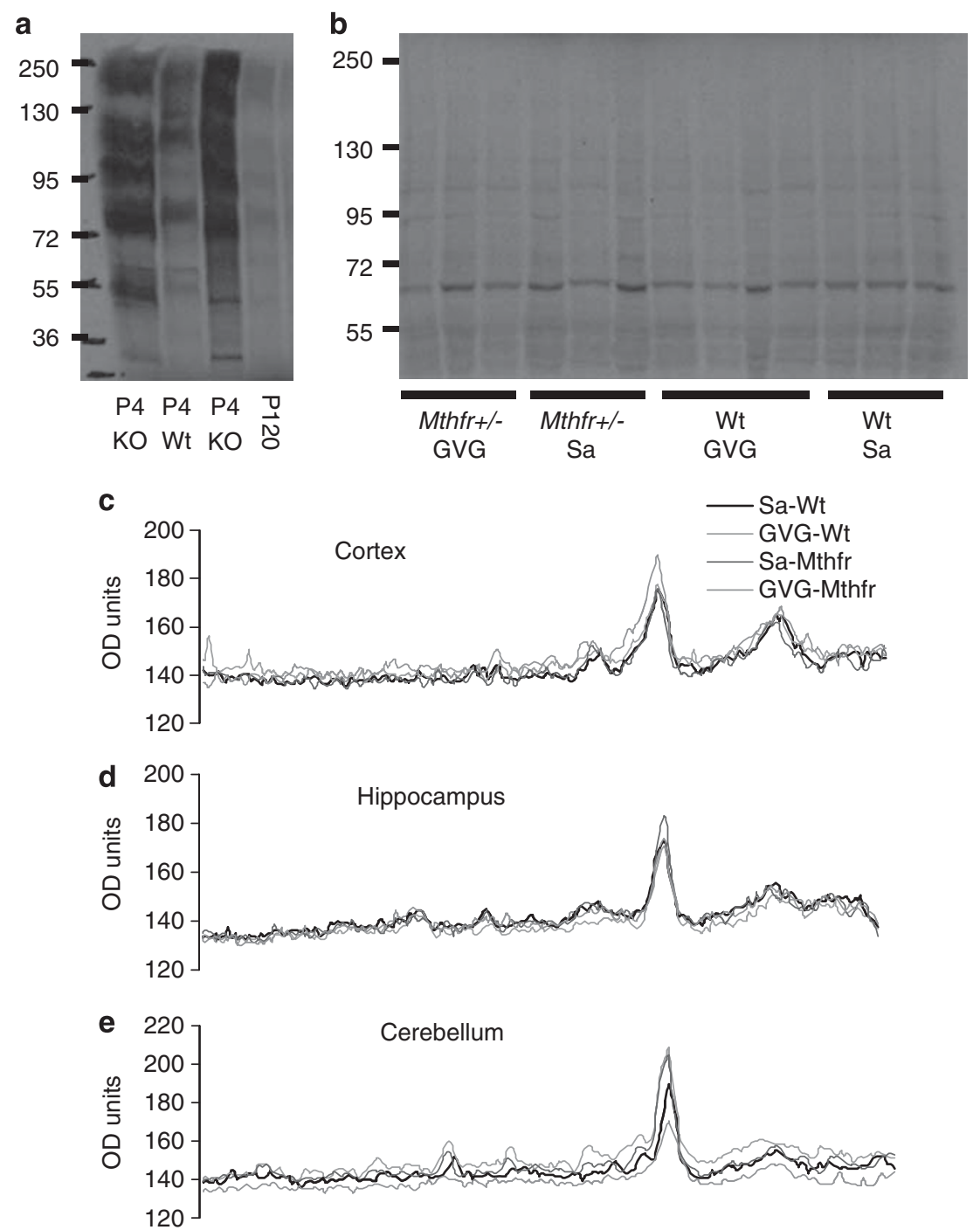

Figure 7 Protein methylation in the female brain. (a) An example of $\mathrm{S}^{35}$ radiolabeled protein. A brain homogenate blot of postnatal day P4 Mthfr-/-, Mthfr + I + (wild type (WT)), and PI20 WT indicating protein hypomethylation in the Mthfr-/ - newborns, higher methylated protein status in P4 WT, and the higher level of methylation observed in the PI20 WT mice (b). An example of radiolabeled protein of female hippocampus homogenate of all tested groups was shown. Line analysis of protein radiolabeled optical density cortex, hippocampus, and cerebellum (c, d, and e, respectively). Each line represents the average value of three samples.

Cannon, 1994). However, when given to pregnant mice, it was shown to alter methionine levels in mice plasma and placenta (Abdulrazzaq et al, 2001, 2005). Although GVG only has a short-term effect on GABA and methionine levels, when it occurs during neurogenesis, it may have long-lasting consequences for the developing brain. The findings of this study suggest a possible interaction of GVG with $M t h f r$ deficiency.

All mice presented low sociability, while control male mice also exhibited a lack of interest in situations of social novelty. This result is not surprising considering that the mutant mice were generated on a Balb/c background (Moy et al, 2007; Panksepp et al, 2008; Chen et al, 2009; Jacome et al, 2011). Moreover, different mouse strains showed asocial behavior on the first, but not the second day of the test, suggesting that the behavior of the mice in the different phases of the test is mediated by different background genes (Moy et al, 2007, 2008). Our data support asocial behavior on the first day of the test regardless of treatment group. Social behavior of male and female mice in a similar paradigm was compared by Moy et al (2004), using a limited number of strains. In these social strains, male and female mice behaved similarly. However, further studies indicated that these mice are not representative of all mice strains, particularly not of strains with low social interest. Recently, strain-dependent sex effects on social behavior were reported (Defensor et al, 2011).

When comparing neonatal GVG treatment and Mthfr $+/-$ genotypes in the current experiments, the effects of each of these factors alone on reelin or FMRP levels were similar, but when combined, the two factors had virtually no effect on protein levels. On the other hand, they had varied effects on the components of the inhibitory system.

Among the factors that contribute to the developmental regulation of AMPAR surface expression and subunit composition is the secreted protein reelin. The long-term 
effects of GVG and Mthfr deficiency on reelin levels suggest a possible influence on spine and synapse structure and function; in particular, reelin was shown to promote synaptic plasticity. The short-term application of reelin in cultured neurons influenced mainly the NMDA receptor subunits NR2A and NR2B (Beffert et al, 2005; Chen et al, 2005), whereas the long-term application of reelin to cultured neurons specifically increased the surface expression of GluR1 and GluR2/3 (Qiu et al, 2006). Moreover, mutant reeler mice have reduced levels of surface GluR1 expression and exhibit clustering (Qiu and Weeber, 2007). Supplementation of reelin to reeler cultured neurons induced the externalization of GluR1, suggesting a direct link between reelin signaling and the surface expression of GluR1. In line with these reports, a correlation between high reelin levels and an enhanced GluR1/GluR2 ratio in the plasma membrane-enriched fraction was found in the cortex of GVG-treated and $M t h f r+/-$ female mice. Dab1 levels in female cortex did not respond to the change in reelin.

In male cortex, modulation of the reelin signaling molecules is genotype dependent; enhanced levels of reelin full-length protein and decreased levels of Dab1 were observed. Despite the modified levels of Dab1, activation of the cellular signaling requires its phosphorylation (Howell et al, 1999; Morimura and Ogawa, 2009), which was not analyzed in this study.

Considering its gender and genotype outcomes on reelin and synaptic proteins, the Mthfr deficiency may modulate synaptic functions differently in female mice than that in male mice.

An additional regulator of AMPAR subunit synthesis and trafficking in neurons is FMRP, known as a suppressor of GluR1 and GluR2/3 local synthesis in dendritic spines (Muddashetty et al, 2007; Schutt et al, 2009). FMRP also has a major role in the regulation of GluR1 and GluR2 internalization in dendritic spines, as FMRP levels correlate negatively with receptor internalization (Nakamoto et al, 2007). In accordance with these reports, excess FMRP may result in a decreased local synthesis and an altered distribution of AMPARs in neurons and synapse membranes. Here, we observed in female mice that FMRP protein levels were enhanced either by GVG or by $M t h f r+/-$ genotype, but not by their combination. Consistent with FMRP's role in the regulation of GluR1 and GluR2, the ratio between the GluR1 and GluR2 subunits in the plasma membrane was modified by GVG and $M t h f r+/-$ genotype. It is possible that the effect of genotype and treatment on GluR1 and GluR2 was localization to the plasma membrane fraction and not to the cytoplasmic fraction due to the enrichment of GluRs in plasma membranes and to the dominance of FMRP as a regulator of GluR synthesis in the spine domain (Muddashetty et al, 2007; Schutt et al, 2009; Pfeiffer and Huber, 2007). Moreover, as in a mature neuron the majority of the GluR protein in the membrane surface is localized in synapses, the plasma membraneenriched fraction is characterized by a high degree of synaptic expression.

FMRP levels in male cortices were affected by neither genotype nor treatment. In agreement with this observation, the GluR1/GluR2 ratio was unaffected in the plasma membrane-enriched fractions in all male groups. On the other hand, there was an increase in cytoplasmic GluR1 levels in male mice treated neonatally by GVG. Thus, in both male and female mice, there was a correlation between FMRP and plasma membrane GluR1/GluR2, whereas cytoplasm GluR1 levels were independent of FMRP levels.

Reelin and FMRP, two molecules associated with the local regulation of synaptic AMPARs, were similarly regulated by Mthfr deficiency and neonatal exposure to GVG in female mice, which also promoted an increase in the membrane GluR1/GluR2 ratio. Changes in the surface expression of GluR1 and GluR2-3 following high-frequency stimulation (Lissin et al, 1998; Carroll et al, 1999; Shi et al, 1999; Hayashi et al, 2000) and different stimulants (Beattie et al, 2002) have been reported previously. An increase in the surface expression of GluR1 subunits was associated with long-term potentiation (Shi et al, 1999; Hayashi et al, 2000), whereas GluR2 was associated with basal transmission and synapse scaling (Malinow and Malenka, 2002; Gainey et al, 2009). Thus, the change observed in the membrane GluR1/ GluR2 ratio in GVG-treated and $M t h f r$-deficient female cortex may imply altered synaptic transmission and frequency response.

As both Fmr1 and reln gene transcription is known to be regulated by DNA methylation (Dong et al, 2005; Hansen et al, 1992), we expected that the global DNA hypomethylation shown in Mthfr-deficient mice (Chen et al, 2001) would affect DNA transcription, resulting in the potentiation of Fmrl and reln expression. However, the Fmr1 gene was unmethylated at the tested site in WT as well as in the $M t h f r$-deficient mice. Accordingly, we did not find any changes in the expression of these genes, which may suggest that the increase in the level of the corresponding proteins may be due to post-transcriptional modification or to lower degradation rates.

Altogether, gender-dependent alterations in important regulatory proteins in the excitatory synapse in the cerebral cortex of GVG-treated and Mthfr-deficient female mice may have a role in social behavior impairment and anxietyrelated behavior as reported previously (Levav-Rabkin et al, 2011). None of the above changes were observed in male mice, supporting a correlation between the behavioral outcome and the change in the tested proteins.

It has been suggested that low levels of reln predispose the brain toward disorders such as autism and schizophrenia, in which the effect of the disorder on social behavior is a predominant feature. However, our findings suggest that higher levels of reelin may also perturb proper synapse function, also resulting in behavioral impairment.

A significant observation in this study comprised the differences between female and male mice, expressed by the response of synaptic proteins to GVG neonatal treatment and $M t h f r+1-$ genotype. Sex hormones, in particular estradiol, have been shown to have a significant influence on various aspects of synaptogenesis and synaptic plasticity. For example, in different regions of the hippocampus, increased dendritic spines and synapse density correlate with enhanced estradiol levels (Woolley and McEwen, 1992; Segal and Murphy, 2001; Bender et al, 2010; Todd et al, 2007). This action of estradiol is mediated by estrogen receptor (ER) $\beta$, which is involved in increased reelin protein levels (Bender et $a l, 2010$ ) and in the levels of PSD95 and of the AMPAR GluR1 subunit (Zadran et al, 
2009; Liu et al, 2008). Enhanced estradiol results in the potentiation of excitatory synaptic potentials and an increased responsiveness to high-frequency stimulation (Liu et al, 2008). Therefore, reduced MTHFR activity and GVG action may interact with estradiol pathways, resulting in an induction of reelin and GluR1.

In contrast, in male mice, ER $\beta$-mediated AMPA stimulation may already be induced by high basal levels of estradiol, and therefore, it cannot undergo further upregulation by genotype or treatment, as shown previously in the ventromedial nucleus of the hypothalamus (Todd et al, 2007). In agreement with this report, the GluR1/GluR2 ratio was enhanced in the cortex of Sa-WT male mice compared with Sa-WT female mice, particularly in the plasma membrane. Moreover, elevated levels of FMRP may promote GluR1 and GluR2 regulation and its localization in the plasma membrane and possibly in the synapse.

Impairment of the GABAeric pathway is associated with altered social behavior and is indicated in autism, schizophrenia, and epilepsy. GAD65 but not GAD67 was regulated by the $M t h f r$ genotype in a gender-dependent manner, and cytoplasmic levels of GABA A $\alpha 2$ and gephyrin were modified in treatment, genotype, and gender-dependent manners.

The proportions of GABA $A \alpha 2$ and gephyrin in the membrane-enriched fraction undergo downregulation by neonatal GABA enhancement and the Mthfr genotype, indicating a possible disruption in GABA receptor clustering and responsiveness (Marchionni et al, 2009; Kneussel et al, 1999; Tretter et al, 2008; Yu et al, 2007). On the other hand, upregulation of GABA A $\alpha 2 /$ gephyrin was genotype dependent and could also indicate impaired function. Despite the derivation of the cytoplasmic and membrane levels of these proteins from the same protein source, it is impossible to make predictions about one based on the other. Therefore, a reduced or elevated ratio of these proteins in the membrane is difficult to interpret, but either suggests a change in basal inhibition properties.

The majority of $\mathrm{ER} \beta$-expressing cells in various brain regions, including the cerebral cortex, are parvalbumin (PV)-immunoreactive neurons (Blurton-Jones and Tuszynski, 2002), which indicates that they are associated with GABAergic transmission. Moreover, estradiol specifically and directly regulates GAD65 transcription via both ER $\alpha$ and ER $\beta$ receptors (Hudgens et al, 2009). Thus, GABA potentiation may distinctively affect GAD65 and other components of the GABAergic system in male and female mice. The lack of an effect by GVG treatment on GAD65, in both male and female cortices as found in our study, may be explained by the prepubertal age of treatment, during which time the estradiol levels in both genders are relatively low. On the other hand, we observed gender-dependent $M t h f r+/$ - genotype effects on GAD65 activation. However, this may be an indirect effect, as previous reports showed that GAD67, but not GAD65, was highly sensitive to methylation status (Dong et al, 2005; Dong et al, 2007).

A variety of post-translational modifications, such as acetylation, phosphorylation, ubiquitylation, and lysine and arginine methylation, can influence protein activity and availability. We tested global protein methylation to determine whether $M t h f r+/-$ genotype and/or treatment produce such an effect. Although a clear difference in protein methylation was observed in the immature brain of $M t h f r$-deficient mice, no clear effect of treatment was detected.

Overall, the results presented here support a significant interaction of gender, $M t h f r$ deficiency, and neonatal GABA potentiation in the regulation of proteins associated with plasticity of the excitatory synapse. Considering the central role the excitatory synapse function has in various neurodevelopmental disorders, this study is a clear demonstration of how several epigenetic factors may predispose the developing brain to be highly susceptible to genetic or environmental factors.

\section{ACKNOWLEDGEMENTS}

This work was supported by the Israel Ministry of Health (No. 3_4030). We thank the Israeli Ministry of Science, Culture, and Sport for the Eshkol Fellowship to Mrs Tamar Levav-Rabkin. Gratitude is also extended to Prof. Rima Rozen from McGill University, Canada, for kindly providing the Mthfr knockout mice, and to Prof. Ruth Parvari and Ms Sofia Borokovsky from the Department of Developmental Genetics, Faculty of Health Sciences, Ben-Gurion University of the Negev, Israel, for their help with the protein methylation assay.

\section{DISCLOSURE}

The authors declare that, except for income received from our primary employer, no financial support or compensation has been received from any individual or corporate entity over the past 3 years for research or professional service and there are no personal financial holdings that could be perceived as constituting a potential conflict of interest.

\section{REFERENCES}

Abdulrazzaq YM, Padmanabhan R, Bastaki Salim MA, Ibrahim A, Bener A (2001). Placental transfer of vigabatrin (gamma-vinyl GABA) and its effect on concentration of amino acids in the embryo of TO mice. Teratology 63: 127-133.

Abdulrazzaq YM, Padmanabhan R, Bastaki SMA, Ibrahim A, Nurulain M, Shafiullah M (2005). Effect of maternal administration of vigabatrin during late gestation on fetoplacental amino acid profile in the mouse. Reprod Toxicol 20: 549-560.

Bagni C, Greenough WT (2005). From mRNP trafficking to spine dysmorphogenesis: the roots of fragile $\mathrm{X}$ syndrome. Nat Rev Neurosci 6: $376-387$.

Beattie EC, Stellwagen D, Morishita W, Bresnahan JC, Ha BK, Von Zastrow $\mathrm{M}$ et al (2002). Control of synaptic strength by glial TNFalpha. Science 295: 2282-2285.

Beffert U, Weeber EJ, Durudas A, Qiu S, Masiulis I, Sweatt JD et al (2005). Modulation of synaptic plasticity and memory by reelin involves differential splicing of the lipoprotein receptor Apoer2. Neuron 47: 567-579.

Bender RA, Zhou L, Wilkars W, Fester L, Lanowski JS, Paysen D et al (2010). Roles of 17 beta\}-estradiol involve regulation of reelin expression and synaptogenesis in the dentate gyrus. Cereb Cortex 20: 2985-2995.

Berton F, Cornet V, Iborra C, Garrido J, Dargent B, Fukuda M et al (2000). Synaptotagmin I and IV define distinct populations of neuronal transport vesicles. Eur J Neurosci 12: 1294-1302. 
Blurton-Jones M, Tuszynski MH (2002). Estrogen receptor-beta colocalizes extensively with parvalbumin-labeled inhibitory neurons in the cortex, amygdala, basal forebrain, and hippocampal formation of intact and ovariectomized adult rats. J Comp Neurol 452: 276-287.

Boris M, Goldblatt A, Galanko J, James SJ (2004). Association of MTHFR gene variants with autism. J Am Phys Surg 9: 106-108.

Carroll RC, Lissin DV, von Zastrow M, Nicoll RA, Malenka RC (1999). Rapid redistribution of glutamate receptors contributes to long-term depression in hippocampal cultures. Nat Neurosci 2: 454-460.

Chen Q, Panksepp JB, Lahvis GP (2009). Empathy is moderated by genetic background in mice. PLoS One 4: e4387.

Chen Y, Beffert U, Ertunc M, Tang TS, Kavalali ET, Bezprozvanny I et al (2005). Reelin modulates NMDA receptor activity in cortical neurons. J Neurosci 25: 8209-8216.

Chen Z, Karaplis AC, Ackerman SL, Pogribny IP, Melnyk S, Lussier-Cacan S et al (2001). Mice deficient in methylenetetrahydrofolate reductase exhibit hyperhomocysteinemia and decreased methylation capacity, with neuropathology and aortic lipid deposition. Hum Mol Genet 10: 433-443.

Chonchaiya W, Schneider A, Hagerman RJ (2009). Fragile X: a family of disorders. Adv Pediatr 56: 165-186.

Crawley JN (1999). Behavioral phenotyping of transgenic and knockout mice: experimental design and evaluation of general health, sensory functions, motor abilities, and specific behavioral tests. Brain Res 835: 18-26.

Crawley JN (2007). Mouse behavioral assays relevant to the symptoms of autism. Brain Pathol (Zurich, Switzerland) 17: 448-459.

Dean JC, Moore SJ, Osborne A, Howe J, Turnpenny PD (1999). Fetal anticonvulsant syndrome and mutation in the maternal MTHFR gene. Clin Genet 56: 216-220.

Defensor EB, Pearson BL, Pobbe RL, Bolivar VJ, Blanchard DC, Blanchard RJ (2011). A novel social proximity test suggests patterns of social avoidance and gaze aversion-like behavior in BTBR T+ tf/J mice. Behav Brain Res 217: 302-308.

Dessens AB, Cohen-Kettenis PT, Mellenbergh GJ, Koppe JG, van De Poll NE, Boer K (2000). Association of prenatal phenobarbital and phenytoin exposure with small head size at birth and with learning problems. Acta Paediatr 89: 533-541.

Dong E, Agis-Balboa RC, Simonini MV, Grayson DR, Costa E, Guidotti A (2005). Reelin and glutamic acid decarboxylase67 promoter remodeling in an epigenetic methionine-induced mouse model of schizophrenia. Proc Natl Acad Sci USA 102: 12578-12583.

Dong E, Guidotti A, Grayson DR, Costa E (2007). Histone hyperacetylation induces demethylation of reelin and $67-\mathrm{kDa}$ glutamic acid decarboxylase promoters. Proc Natl Acad Sci USA 104: $4676-4681$.

Feng LG, Song ZW, Xin F, Hu J (2009). Association of plasma homocysteine and methylenetetrahydrofolate reductase C677T gene variant with schizophrenia: a Chinese Han populationbased case-control study. Psychiatry Res 168: 205-208.

Frosst P, Blom HJ, Milos R, Goyette P, Sheppard CA, Matthews RG et al (1995). A candidate genetic risk factor for vascular disease: a common mutation in methylenetetrahydrofolate reductase. Nat Genet 10: 111-113.

Gainey MA, Hurvitz-Wolff JR, Lambo ME, Turrigiano GG (2009). Synaptic scaling requires the GluR2 subunit of the AMPA receptor. J Neurosci 29: 6479-6489.

Gilbody S, Lewis S, Lightfoot T (2007). Methylenetetrahydrofolate reductase (MTHFR) genetic polymorphisms and psychiatric disorders: a HuGE review. Am J Epidemiol 165: 1-13.

Goin-Kochel RP, Porter AE, Peters SU, Shinawi M, Sahoo T, Beaudet AL (2009). The MTHFR 677C $\rightarrow \mathrm{T}$ polymorphism and behaviors in children with autism: exploratory genotypephenotype correlations. Autism Res 2: 98-108.
Hansen RS, Gartler SM, Scott CR, Chen SH, Laird CD (1992). Methylation analysis of CGG sites in the CpG island of the human FMR1 gene. Hum Mol Genet 1: 571-578.

Hayashi Y, Shi SH, Esteban JA, Piccini A, Poncer JC, Malinow R (2000). Driving AMPA receptors into synapses by LTP and CaMKII: requirement for GluR1 and PDZ domain interaction. Science 287: 2262-2267.

Howell BW, Herrick TM, Cooper JA (1999). Reelin-induced tyrosine (corrected) phosphorylation of disabled 1 during neuronal positioning. Genes Dev 13: 643-648.

Hu H, Qin Y, Bochorishvili G, Zhu Y, van Aelst L, Zhu JJ (2008). Ras signaling mechanisms underlying impaired GluR1dependent plasticity associated with fragile $\mathrm{X}$ syndrome. J Neurosci 28: 7847-7862.

Hudgens ED, Ji L, Carpenter CD, Petersen SL (2009). The gad2 promoter is a transcriptional target of estrogen receptor (ER)alpha and ER beta: a unifying hypothesis to explain diverse effects of estradiol. J Neurosci 29: 8790-8797.

Huttner WB, Schiebler W, Greengard P, De Camilli P (1983). Synapsin I (protein I), a nerve terminal-specific phosphoprotein. III. Its association with synaptic vesicles studied in a highly purified synaptic vesicle preparation. $J$ Cell Biol 96: 1374-1388.

Jacome LF, Burket JA, Herndon AL, Cannon WR, Deutsch SI (2011). D-serine improves dimensions of the sociability deficit of the genetically-inbred Balb/c mouse strain. Brain Res Bull 84: 12-16.

Jacques PF, Bostom AG, Williams RR, Ellison RC, Eckfeldt JH, Rosenberg IH et al (1996). Relation between folate status, a common mutation in methylenetetrahydrofolate reductase, and plasma homocysteine concentrations. Circulation 93: 7-9.

Kluijtmans LA, Young IS, Boreham CA, Murray L, McMaster D, McNulty $\mathrm{H}$ et al (2003). Genetic and nutritional factors contributing to hyperhomocysteinemia in young adults. Blood 101: 2483-2488.

Kneussel M, Brandstatter JH, Laube B, Stahl S, Muller U, Betz H (1999). Loss of postsynaptic GABA(A) receptor clustering in gephyrin-deficient mice. J Neurosci 19: 9289-9297.

Levav T, Saar T, Berkovich L, Golan H (2004). Perinatal exposure to GABA-transaminase inhibitor impaired psychomotor function in the developing and adult mouse. Int J Dev Neurosci 22: 137-147.

Levav T, Wirthaim O, Weiss R, Grossman Y, Golan H (2008). Impaired synaptogenesis and long-term modulation of behavior following postnatal elevation of GABA levels in mice. Neuropharmacology 54: 387-398.

Levav-Rabkin T, Blumkin E, Galron D, Golan HM (2011). Sex-dependent behavioral effects of Mthfr deficiency and neonatal Gaba potentiation in mice. Behav Brain Res 216: 505-513.

Levav-Rabkin T, Melamed O, Clarke G, Farber M, Cryan JF, Dinan TG et al (2010). A sensitive period of mice inhibitory system to neonatal GABA enhancement by vigabatrin is brain region dependent. Neuropsychopharmacology 35: 1138-1154.

Lewis DA, Pierri JN, Volk DW, Melchitzky DS, Woo TU (1999). Altered GABA neurotransmission and prefrontal cortical dysfunction in schizophrenia. Biol Psychiatry 46: 616-626.

Lissin DV, Gomperts SN, Carroll RC, Christine CW, Kalman D, Kitamura $\mathrm{M}$ et al (1998). Activity differentially regulates the surface expression of synaptic AMPA and NMDA glutamate receptors. Proc Natl Acad Sci USA 95: 7097-7102.

Liu F, Day M, Muniz LC, Bitran D, Arias R, Revilla-Sanchez R et al (2008). Activation of estrogen receptor-beta regulates hippocampal synaptic plasticity and improves memory. Nat Neurosci 11: 334-343.

Malinow R, Malenka RC (2002). AMPA receptor trafficking and synaptic plasticity. Annu Rev Neurosci 25: 103-126. 
Marchionni I, Kasap Z, Mozrzymas JW, Sieghart W, Cherubini E, Zacchi P (2009). New insights on the role of gephyrin in regulating both phasic and tonic GABAergic inhibition in rat hippocampal neurons in culture. Neuroscience 164: 552-562.

Morimura T, Ogawa M (2009). Relative importance of the tyrosine phosphorylation sites of disabled-1 to the transmission of reelin signaling. Brain Res 1304: 26-37.

Moy SS, Nadler JJ, Perez A, Barbaro RP, Johns JM, Magnuson TR et al (2004). Sociability and preference for social novelty in five inbred strains: an approach to assess autistic-like behavior in mice. Genes Brain Behav 3: 287-302.

Moy SS, Nadler JJ, Young NB, Nonneman RJ, Segall SK, Andrade GM et al (2008). Social approach and repetitive behavior in eleven inbred mouse strains. Behav Brain Res 191: 118-129.

Moy SS, Nadler JJ, Young NB, Perez A, Holloway LP, Barbaro RP et al (2007). Mouse behavioral tasks relevant to autism: phenotypes of 10 inbred strains. Behav Brain Res 176: 4-20.

Muddashetty RS, Kelic S, Gross C, Xu M, Bassell GJ (2007). Dysregulated metabotropic glutamate receptor-dependent translation of AMPA receptor and postsynaptic density-95 mRNAs at synapses in a mouse model of fragile X syndrome. J Neurosci 27: 5338-5348.

Mumford JP, Cannon DJ (1994). Vigabatrin. Epilepsia 35(Suppl 5): S25-S28.

Nadler JJ, Moy SS, Dold G, Trang D, Simmons N, Perez A et al (2004). Automated apparatus for quantitation of social approach behaviors in mice. Genes Brain Behav 3: 303-314.

Nakamoto M, Nalavadi V, Epstein MP, Narayanan U, Bassell GJ, Warren ST (2007). Fragile X mental retardation protein deficiency leads to excessive mGluR5-dependent internalization of AMPA receptors. Proc Natl Acad Sci USA 104: 15537-15542.

Niu S, Renfro A, Quattrocchi CC, Sheldon M, D’Arcangelo G (2004). Reelin promotes hippocampal dendrite development through the VLDLR/ApoER2-Dab1 pathway. Neuron 41: 71-84.

Niu S, Yabut O, D'Arcangelo G (2008). The reelin signaling pathway promotes dendritic spine development in hippocampal neurons. J Neurosci 28: 10339-10348.

Ono H, Sakamoto A, Mizoguchi N, Sakura N (2002). The C677T mutation in the methylenetetrahydrofolate reductase gene contributes to hyperhomocysteinemia in patients taking anticonvulsants. Brain Dev 24: 223-226.

Panksepp JB, Wong JC, Kennedy BC, Lahvis GP (2008). Differential entrainment of a social rhythm in adolescent mice. Behav Brain Res 195: 239-245.

Pfeiffer BE, Huber KM (2007). Fragile X mental retardation protein induces synapse loss through acute postsynaptic translational regulation. J Neurosci 27: 3120-3130.

Pujadas L, Gruart A, Bosch C, Delgado L, Teixeira CM, Rossi D et al (2010). Reelin regulates postnatal neurogenesis and enhances spine hypertrophy and long-term potentiation. J Neurosci 30: 4636-4649.

Qiao M, Malisza KL, Del Bigio MR, Kozlowski P, Seshia SS, Tuor UI (2000). Effect of long-term vigabatrin administration on the immature rat brain. Epilepsia 41: 655-665.

Qiu S, Weeber EJ (2007). Reelin signaling facilitates maturation of CA1 glutamatergic synapses. J Neurophysiol 97: 2312-2321.

Qiu S, Zhao LF, Korwek KM, Weeber EJ (2006). Differential reelininduced enhancement of NMDA and AMPA receptor activity in the adult hippocampus. J Neurosci 26: 12943-12955.

Qume M, Whitton PS, Fowler LJ (1995). The effect of chronic treatment with the GABA transaminase inhibitors gammavinyl-GABA and ethanolamine- $O$-sulphate on the in vivo release of GABA from rat hippocampus. J Neurochem 64: 2256-2261.

Rasalam AD, Hailey H, Williams JH, Moore SJ, Turnpenny PD, Lloyd DJ et al (2005). Characteristics of fetal anticonvulsant syndrome associated autistic disorder. Dev Med Child Neurol 47: 551-555.
Regland B, Germgard T, Gottfries CG, Grenfeldt B, Koch-Schmidt AC (1997). Homozygous thermolabile methylenetetrahydrofolate reductase in schizophrenia-like psychosis. J Neural Transm 104: 931-941.

Roy M, Leclerc D, Wu Q, Gupta S, Kruger WD, Rozen R (2008). Valproic acid increases expression of methylenetetrahydrofolate reductase (MTHFR) and induces lower teratogenicity in MTHFR deficiency. $J$ Cell Biochem 105: 467-476.

Schutt J, Falley K, Richter D, Kreienkamp HJ, Kindler S (2009). Fragile X mental retardation protein regulates the levels of scaffold proteins and glutamate receptors in postsynaptic densities. J Biol Chem 284: 25479-25487.

Segal M, Murphy D (2001). Estradiol induces formation of dendritic spines in hippocampal neurons: functional correlates. Horm Behav 40: 156-159.

Sener U, Zorlu Y, Karaguzel O, Ozdamar O, Coker I, Topbas M (2006). Effects of common anti-epileptic drug monotherapy on serum levels of homocysteine, vitamin B12, folic acid and vitamin B6. Seizure 15: 79-85.

Serajee FJ, Zhong H, Mahbubul Huq AH (2006). Association of reelin gene polymorphisms with autism. Genomics 87: $75-83$.

Shi SH, Hayashi Y, Petralia RS, Zaman SH, Wenthold RJ, Svoboda $\mathrm{K}$ et al (1999). Rapid spine delivery and redistribution of AMPA receptors after synaptic NMDA receptor activation. Science 284: $1811-1816$.

Skaar DA, Shao Y, Haines JL, Stenger JE, Jaworski J, Martin ER et al (2005). Analysis of the RELN gene as a genetic risk factor for autism. Mol Psychiatry 10: 563-571.

Snow K, Doud LK, Hagerman R, Pergolizzi RG, Erster SH, Thibodeau SN (1993). Analysis of a CGG sequence at the FMR-1 locus in fragile $\mathrm{X}$ families and in the general population. $A m \mathrm{~J}$ Hum Genet 53: 1217-1228.

Suvrathan A, Hoeffer CA, Wong H, Klann E, Chattarji S (2010). Characterization and reversal of synaptic defects in the amygdala in a mouse model of fragile X syndrome. Proc Natl Acad Sci USA 107: 11591-11596.

Todd BJ, Schwarz JM, Mong JA, McCarthy MM (2007). Glutamate AMPA/kainite receptors, not GABA(A) receptors, mediate estradiol-induced sex differences in the hypothalamus. Dev Neurobiol 67: 304-315.

Tretter V, Jacob TC, Mukherjee J, Fritschy JM, Pangalos MN, Moss SJ (2008). The clustering of GABA(A) receptor subtypes at inhibitory synapses is facilitated via the direct binding of receptor alpha 2 subunits to gephyrin. J Neurosci 28: 1356-1365.

Vares M, Saetre P, Deng H, Cai G, Liu X, Hansen T et al (2010). Association between methylenetetrahydrofolate reductase (MTHFR) C677T polymorphism and age of onset in schizophrenia. Am J Med Genet B 153B: 610-618.

Vilaseca MA, Monros E, Artuch R, Colome C, Farre C, Valls C et al (2000). Anti-epileptic drug treatment in children: hyperhomocysteinaemia, B-vitamins and the $677 \mathrm{C} \rightarrow \mathrm{T}$ mutation of the methylenetetrahydrofolate reductase gene. Eur J Paediatr Neurol 4: $269-277$.

Volpe J 2001. Neurology of the Newborn, 4th edn. WB Saunders: Philadelphia. pp 178-211.

Vurucu S, Demirkaya E, Kul M, Unay B, Gul D, Akin R et al (2008). Evaluation of the relationship between C677T variants of methylenetetrahydrofolate reductase gene and hyperhomocysteinemia in children receiving antiepileptic drug therapy. Progr Neuro-Psychopharmacol Biol Psychiatry 32: 844-848.

Wang DD, Kriegstein AR (2009). Defining the role of GABA in cortical development. J Physiol 587: 1873-1879.

Weiler IJ, Greenough WT (1999). Synaptic synthesis of the Fragile $\mathrm{X}$ protein: possible involvement in synapse maturation and elimination. Am J Med Genet 83: 248-252. 
Woolley CS, McEwen BS (1992). Estradiol mediates fluctuation in hippocampal synapse density during the estrous cycle in the adult rat. J Neurosci 12: 2549-2554.

Yoo JH, Hong SB (1999). A common mutation in the methylenetetrahydrofolate reductase gene is a determinant of hyperhomocysteinemia in epileptic patients receiving anticonvulsants. Metab Clin Exp 48: 1047-1051.
Yu W, Jiang M, Miralles CP, Li RW, Chen G, de Blas AL (2007). Gephyrin clustering is required for the stability of GABAergic synapses. Mol Cell Neurosci 36: 484-500.

Zadran S, Qin Q, Bi X, Zadran H, Kim Y, Foy MR et al (2009). 17Beta-estradiol increases neuronal excitability through MAP kinase-induced calpain activation. Proc Natl Acad Sci USA 106: 21936-21941.

Supplementary Information accompanies the paper on the Neuropsychopharmacology website (http://www.nature.com/npp) 